\title{
Evaluating anti-Orthopoxvirus antibodies in individuals from Brazilian rural areas prior to the bovine vaccinia era
}

\author{
Poliana de Oliveira Figueiredo ${ }^{1}$, André Tavares da Silva-Fernandes' ${ }^{1}$ Bruno Eduardo Fernandes Mota', \\ Galileu Barbosa Costa', Iara Apolinário Borges ${ }^{1}$, Paulo César Peregrino Ferreira', \\ Jônatas Santos Abrahão', Erika Martins Braga², Erna Geessien Kroon ${ }^{1}$, Giliane de Souza Trindade ${ }^{1 /+}$ \\ ${ }^{1}$ Universidade Federal de Minas Gerais, Instituto de Ciências Biológicas, Departamento de Microbiologia, Laboratório de Vírus, \\ Belo Horizonte, MG, Brasil ²Universidade Federal de Minas Gerais, Instituto de Ciências Biológicas, \\ Departamento de Parasitologia, Laboratório de Malária, Belo Horizonte, MG, Brasil
}

Vaccinia virus naturally circulates in Brazil and is the causative agent of a zoonotic disease known as bovine vaccinia $(B V)$. We retrospectively evaluated two populations from the Amazon and Southeast Regions. BV outbreaks had not been reported in these regions before sample collection. Neutralising antibodies were found in 13 individuals $(n=$ 132) with titres ranging from $100 \geq 6,400$ neutralising units $/ \mathrm{mL}$. Univariate analysis identified age and vaccination as statistically significant risk factors in individuals from the Southeast Region. The absence of detectable antibodies in vaccinated individuals raises questions about the protection of smallpox vaccine years after vaccination and reinforces the need for surveillance of Orthopoxvirus in Brazilian populations without evidence of previous outbreaks.

Key words: Orthopoxvirus - smallpox vaccine - bovine vaccinia - retrospective serosurvey

Thirty-four years ago, the world celebrated the eradication of smallpox, a lethal disease caused by Variola virus infection. The massive antismallpox vaccination campaign was promoted by the World Health Organization (WHO) during the 1960's and 1970's (Fenner et al. 1988, Damon 2013). Vaccinia virus (VACV), a species belonging to the Orthopoxvirus (OPV) genus that demonstrates serological cross-reactivity with other OPV species, was used as the vaccine antigen during the WHO campaign. Following smallpox eradication in the late 1970's, vaccination was suspended due to several instances of adverse reactions to the vaccine (Cono et al. 2003).

The natural circulation of VACV began to be reported in Brazil in 1999 and has been associated with several exanthematic VACV outbreaks that have been described in Brazilian rural areas (da Fonseca et al. 2011, Kroon et al. 2011, Singh et al. 2012, Shchelkunov 2013). VACV infection causes lesions on the teats and udders of dairy cattle, leading to a decrease in milk production. VACV is the cause of a zoonotic disease known as bovine vaccinia (BV) and can be transmitted to humans by direct contact with infected animals during milking, resulting in lesions on the hands and arms (Damaso et al. 2000, Trindade et al. 2003, 2007, 2009, Leite et al. 2005, Lobato et al. 2005, Megid et al. 2008, Silva-Fernandes et al. 2009, Abrahão et al. 2010a, Schatzmayr et al. 2011, de Assis

doi: 10.1590/0074-02760150215

Financial support: CNPq, CAPES, FAPEMIG, PRPq-UFMG GST, PCPF, EMB and EGK are researchers from CNPq.

+ Corresponding author: giliane@icb.ufmg.br

Received 8 June 2015

Accepted 13 July 2015 et al. 2013, de Sant'Ana et al. 2013). The lesions evolve from macules to papules to vesicles to pustules, which ulcerate and result in scar formation. Nonspecific symptoms such as fever and lymphadenopathy can also be observed in most infected individuals (Silva-Fernandes et al. 2009, Trindade et al. 2009). The transmission of VACV is associated with unprotected contact between BV-affected cattle and milkers.

Although BV outbreaks associated with vaccine strains were reported during the smallpox eradication campaigns in Latin America and Asia (Fenner et al. 1988), these notifications ceased after vaccination suspension, with only a few cases reported in the 1980's in Southeast Brazil related to contact with cows during milking (Silva et al. 1986). It remains unclear why BV outbreaks have re-emerged after 20 years of absence. Possible explanations for the lack of reported cases for decades include the effective immune response generated by massive smallpox vaccination during the 1970's, significant under-reporting leading to misdiagnoses and the absence of a specific government-enforced surveillance policy (Trindade et al. 2009, da Fonseca et al. 2011). Despite the fact that these outbreaks, as well as the individuals affected by each case, seem to be systematically increasing from year to year both in quantity and in geographic distribution, there remains no officially reported number of human cases across the country.

Theories that propose VACV circulation and maintenance in Brazilian forests have gained attention in recent years, mainly after the detection of VACV in wild and peridomestic animals (Abrahão et al. 2009, 2010b, Peres et al. 2013). Indeed, VACV strains were previously detected in wild and sentinel rodents from the Brazilian Amazon and southeastern forests in the 1960's and 1970's (Lopes et al. 1965, Fonseca et al. 1998). Thus, human exposure to VACV could be related to activities distinct from milking, as suggested by Mota et al. (2010). 
Although there are numerous studies related to the occurrence of VACV in Brazil, little is known about antiOPV immunity in vulnerable populations. A recent study performed by our research group identified a low prevalence of OPV immunity in laboratory workers (Costa et al. 2013). However, most studies have concentrated their efforts on the analysis of humoral responses in patients affected by BV outbreaks or in rural areas where the occurrence of BV has never been reported (Silva-Fernandes et al. 2009, Mota et al. 2010). Indeed, there are no data thus far regarding humoral immunity to OPV in rural populations at high risk of VACV infection.

The present study retrospectively analysed serological protection against OPV in two Brazilian populations from the Amazon and Southeast Regions, where BV cases have not been observed since the late 1990's. Our results raise interesting questions regarding VACV circulation in Brazil in the period preceding the onset of the 1999 BV outbreaks and the levels of protection in these populations today.

We analysed 62 sera samples from the municipality of Mantena, in the state of Minas Gerais (18 ${ }^{\circ} 46^{\prime} 55^{\prime} \mathrm{S}$ $40^{\circ} 58^{\prime} 48^{\prime \prime} \mathrm{W}$ ) and 70 sera samples from the municipality of Terra Nova do Norte, in the state of Mato Grosso $\left(10^{\circ} 31^{\prime} 01^{\prime \prime} \mathrm{S} 55^{\circ} 13^{\prime} 51^{\prime \prime} \mathrm{W}\right)$ (Figure). These samples were collected between 1995-1996 as part of a malaria field investigation (Braga et al. 1997, 2002). Ethical approval for this study was granted by the Research Ethical Committee at the Federal University of Minas Gerais under registration protocol FR-413704. Written informed consent was obtained from all study participants or from their parents (Braga et al. 1997, 2002).

Plaque reduction neutralization tests (PRNT) were run with VACV-Western Reserve (WR) strains as controls, as previously described by Newman et al. (2003) with modifications and recently by our team (Costa et al. 2013). Briefly, serum samples were heated to $56^{\circ} \mathrm{C}$ for 30 min to denature complement system proteins and then diluted in Eagle's minimum essential medium (MEM)

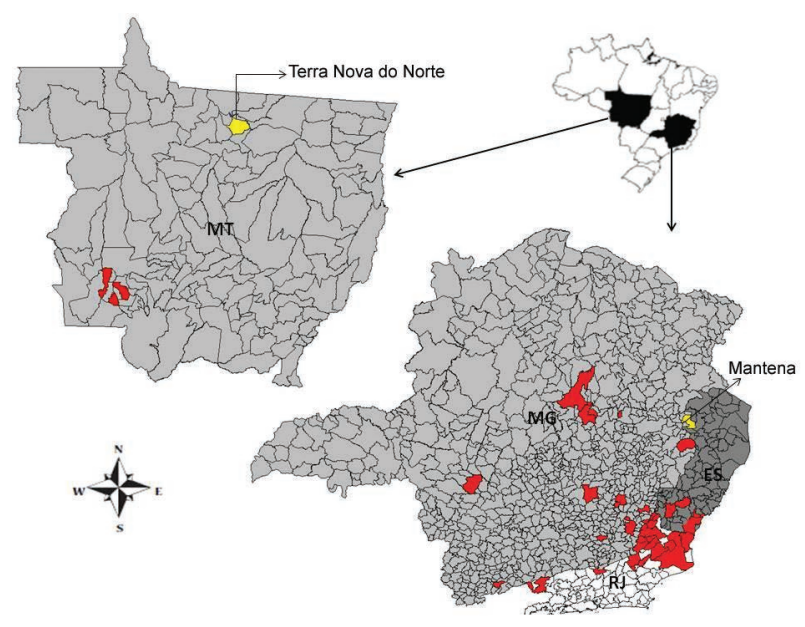

Regions with bovine vaccinia notification after 1995 (red). Brazilian states: Espírito Santo (ES), Minas Gerais (MG), Mato Grosso (MT), Rio de Janeiro (RJ). free of foetal bovine serum (FBS) to a screening ratio of 1:40. Samples were added to the same volume (1:1) of a solution containing approximately 100 plaque-forming units of VACV-WR. This mixture was incubated for $16 \mathrm{~h}$ at $37^{\circ} \mathrm{C}$. Six-well plates containing BSC-40 cells monolayers were inoculated with the mixture. Plates were incubated at $37^{\circ} \mathrm{C}$ for $1 \mathrm{~h}$ in an atmosphere with $5 \% \mathrm{CO}_{2}$. MEM supplemented with 2\% FBS were added to each well and incubated again at $37^{\circ} \mathrm{C}$ with $5 \% \mathrm{CO}_{2}$ for 48 h. Cell monolayers were fixed with $10 \%$ formalin and stained with $1 \%$ crystal violet solution. A sample that inhibited $50 \%$ of plaque formation was considered positive for neutralising antibodies. Samples were tested in triplicate and all positives were titrated.

Epidemiological information, such as gender, age and occupation, were also available. These data were converted into variables and tested to assess their relationship to the presence or absence of neutralising antibodies. Eight samples from Terra Nova do Norte were missing epidemiological information; thus, only 62 samples were considered for statistical analysis. Data were collected using the open access software EpiData (provided by the Pan-American Health Organization) and analysed using chi-square or Fisher's exact tests, as appropriate.

The overall seroprevalence of anti-OPV neutralising antibodies was $9.84 \%$ (13 individuals from the 132 tested) with titres ranging from $100 \geq 6400$ neutralising units/ $\mathrm{mL}$. This figure was three times lower when compared with the prevalence of $27.89 \%$ observed in the Amazon Region (82 individuals from 294 tested) (Mota et al. 2010) and much lower when compared to studies performed in African regions (Lederman et al. 2007, Reynolds et al. 2010). However, our survey showed a high prevalence in relation to a study conducted in Sierra Leone (MacNeil et al. 2011). All previous studies used ELISA tests to detect anti-OPV antibodies. ELISA is a biochemical test that detects all antibodies by class, while the PRNT is a biological test that detects specific neutralising antibodies and is considered the gold standard approach for serological diagnosis (Storch \& Wang 2013).

In addition to these technical differences, other factors that may have contributed to differences in observed prevalence rates include cultural and behavioural differences for risk/exposure factors for OPV infection and patterns of virus circulation in the regions studied. In Brazil, OPV infections are related to outbreaks affecting dairy cattle (Damaso et al. 2000, Trindade et al. 2003, 2007, 2009, Leite et al. 2005, Lobato et al. 2005, Megid et al. 2008, Silva-Fernandes et al. 2009, Abrahão et al. 2010a, Schatzmayr et al. 2011, de Assis et al. 2013, de Sant'Ana et al. 2013) and laboratory activities (Costa et al. 2013). In Africa, exposure to OPV is mainly related to hunting for food, working and living close to sylvan animals, passing through forested areas, as well as secondary human transmission (person-to-person transmission between family members living in the same household) (Reynolds et al. 2010, Damon 2011).

The seropositive individuals found in this study had been vaccinated and included six males and seven females. Nine of these individuals were from Mantena. The median age in both locations was 27 years and ranged from 11-64 
TABLE I

Analysis of the characteristics of the population of Mantena, state of Minas Gerais, Brazil, according to the seropositivity for anti-Orthopoxvirus neutralising antibodies

\begin{tabular}{|c|c|c|c|c|}
\hline Variables & $\begin{array}{c}\text { Tested } \\
\text { individuals } \\
\mathrm{n}(\%)^{a}\end{array}$ & $\begin{array}{c}\text { PRNT } \\
\text { positives } \\
\mathrm{n}(\%)\end{array}$ & $\begin{array}{c}\text { PRNT } \\
\text { negatives } \\
\text { n }(\%)\end{array}$ & $\mathrm{p}^{b}$ \\
\hline \multicolumn{5}{|l|}{ Gender } \\
\hline Male & $31(50)$ & $5(16.1)$ & $26(83.9)$ & 1.000 \\
\hline Female & $31(50)$ & $4(12.9)$ & $27(87.1)$ & \\
\hline \multicolumn{5}{|l|}{ Age (years) } \\
\hline$\leq 18$ & $19(30.6)$ & $0(0)$ & $19(100)$ & 0.006 \\
\hline $19-26$ & $12(19.4)$ & $1(8.3)$ & $11(91.7)$ & \\
\hline $27-36$ & $11(17.8)$ & $6(54.5)$ & $5(45.5)$ & \\
\hline$>36$ & $20(32.2)$ & $2(10)$ & $18(90)$ & \\
\hline \multicolumn{5}{|c|}{ Vaccination status } \\
\hline Yes & $42(67.8)$ & $9(21.5)$ & $33(78.5)$ & 0.047 \\
\hline No & $20(32.2)$ & $0(0)$ & $20(100)$ & \\
\hline Total & $62(100)$ & $9(14.5)$ & $53(85.5)$ & \\
\hline
\end{tabular}

$a$ : frequency of tested individuals per category; $b$ : Fisher's exact test; PRNT: plaque reduction neutralization test.

years in Terra Nova do Norte and from eight-76 years in Mantena. Summary statistics such as demographic data, occupation and vaccination status by regional population are shown in Tables I, II. Statistical analyses showed significant associations when neutralising antibodies were grouped by age and vaccination status (Table I).

The higher proportion of vaccinated individuals without neutralising antibodies in both populations (n $=77 ; 85.5 \%$ ) could be explained by a myriad of factors which may be unrelated to vaccination, as this was a retrospective study and the subjects under investigation were chosen in the context of a study on malaria infection and circulation (Braga et al. 1997, 2002). Thus, when samples were obtained, no efforts were made to look specifically for subjects with clinical indications of previous OPV infection or to determine if the individuals had been successfully vaccinated, which is known to show a strong correlation with smallpox vaccination. Additionally, as discussed by Fenner et al. (1988), there was variable efficacy in the smallpox vaccines produced in Brazil. The distribution channels throughout different Brazilian geographical areas, in addition to inadequate transportation systems and cold chains, sometimes failed to meet accepted quality standards.

Many authors have demonstrated that anti-OPV immunity persists for decades (Hammarlund et al. 2003, Hatakeyama et al. 2005, Kim et al. 2007, Taub et al. 2008). Indeed, high anti-OPV neutralising antibody titres and statistically significant associations between age $(\mathrm{p}=$ $0.0006)$ and vaccination status $(p=0.047)$ were found in individuals from Mantena (Table I). This finding might be explained by the quality of vaccine or quantity of doses received, although maintenance of the cold chain may have been broken before the smallpox vaccine reached rural populations residing in places with difficult access
(Fenner et al. 1988). On the other hand, the high titres found in this population could also suggest that human exposure to OPV in these regions may have occurred prior to the BV era, indicating silent VACV circulation and exposure. Indeed, a previous study demonstrated anti-OPV immunity in Brazilian rural populations in the absence of VACV outbreaks (Mota et al. 2010).

Several factors can contribute to the presence of antibodies in response to OPV infection (Lederman et al. 2007, Kennedy et al. 2009, Mota et al. 2010, Reynolds et al. 2010, Costa et al. 2013). In our statistical analyses, occupation did not enhance the risk of OPV exposure or the presence of neutralising antibodies in individuals from Terra Nova do Norte, despite the fact that farmers (mainly cattle handlers) are directly affected by BV (Trindade et al. 2003, 2007, 2009, Leite et al. 2005, Lobato et al. 2005, Megid et al. 2008, Silva-Fernandes et al. 2009, Abrahão et al. 2010a, Schatzmayr et al. 2011, de Assis et al. 2013, de Sant'Ana et al. 2013).

In conclusion, knowledge of increasing OPV infections and the discovery of novel zoonotic OPV (Vora et al. 2015) pose a continuous and growing threat to human health and information on their epidemiologic features is important in order to prevent new outbreaks. Indeed, VACV seroprevalence studies in Brazil are scarce and most studies conducted in the country to date have focused on outbreak investigation. Furthermore, the absence of neutralising antibodies in vaccinated individuals found in this study and the current occurrence of VACV in all Brazilian territories reinforces the need for OPV surveillance regardless of known outbreaks. Our findings also highlight the need to strengthen global surveillance of OPV infections in both humans and animals (Shchelkunov 2013, Vora et al. 2015). Additional epidemiological studies are ongoing that will further contri- 
TABLE II

Analysis of the characteristics of the population of Terra Nova do Norte, state of Mato Grosso, Brazil, according to the seropositivity for anti-Orthopoxvirus neutralising antibodies

\begin{tabular}{|c|c|c|c|c|}
\hline Variables & $\begin{array}{c}\text { Tested } \\
\text { individuals } \\
\mathrm{n}(\%)^{a}\end{array}$ & $\begin{array}{c}\text { PRNT } \\
\text { positives } \\
\mathrm{n}(\%)\end{array}$ & $\begin{array}{c}\text { PRNT } \\
\text { negatives } \\
\text { n }(\%)\end{array}$ & $\mathrm{p}^{b}$ \\
\hline \multicolumn{5}{|l|}{ Gender } \\
\hline Male & $40(57.2)$ & $1(16.1)$ & $39(83.9)$ & \multirow[t]{3}{*}{0.291} \\
\hline Female & $25(35.7)$ & $3(12.9)$ & $22(87.1)$ & \\
\hline No data & $5(7.1)$ & $0(0)$ & $5(100)$ & \\
\hline \multicolumn{5}{|l|}{ Age (years) } \\
\hline$\leq 18$ & $11(15.7)$ & $0(0)$ & $11(100)$ & \multirow{5}{*}{0.299} \\
\hline $19-26$ & $18(25.7)$ & $2(11.1)$ & $16(88.9)$ & \\
\hline $27-36$ & $16(22.9)$ & $2(12.5)$ & $14(87.5)$ & \\
\hline$>36$ & $18(25.7)$ & $0(0)$ & $18(100)$ & \\
\hline No data & $7(10)$ & $0(0)$ & $7(100)$ & \\
\hline \multicolumn{5}{|c|}{ Vaccination status } \\
\hline Yes & $48(68.6)$ & $4(8.3)$ & 44 (91.7) & \multirow[t]{3}{*}{0.564} \\
\hline No & $15(21.4)$ & $0(0)$ & $15(100)$ & \\
\hline No data & $7(10)$ & $0(0)$ & $7(100)$ & \\
\hline \multicolumn{5}{|l|}{ Occupation } \\
\hline Gold miner & $17(24.3)$ & $0(0)$ & $17(100)$ & \multirow[t]{4}{*}{0.618} \\
\hline Farmer & $27(38.6)$ & $2(7.4)$ & $25(92.6)$ & \\
\hline Others & $20(28.5)$ & $2(10)$ & $18(90)$ & \\
\hline No data & $6(8.6)$ & $0(0)$ & $6(100)$ & \\
\hline Total & $70(100)$ & $4(5.7)$ & $66(94.3)$ & \\
\hline
\end{tabular}

$a$ : frequency of tested individuals per category; $b$ : Fisher's exact test; PRNT: plaque reduction neutralization test.

bute to our understanding of OPV epidemiology by elucidating OPV-vulnerable populations and characterising OPV silent circulation in the absence of outbreaks.

\section{ACKNOWLEDGEMENTS}

To João Rodrigues dos Santos and colleagues from the Virus Lab, ICB-UFMG, for technical support.

\section{REFERENCES}

Abrahão JS, Guedes MI, Trindade GS, Fonseca FG, Campos RK, Mota BF, Lobato ZI, Silva-Fernandes AT, Rodrigues GO, Lima LS, Ferreira PC, Bonjardim CA, Kroon EG 2009. One more piece in the VACV ecological puzzle: could peridomestic rodents be the link between wildlife and bovine Vaccinia outbreaks in Brazil? PLOS ONE 4: e7428.

Abrahão JS, Silva-Fernandes AT, Assis FL, Guedes MI, Drumond BP, Leite JA, Coelho LF, Turrini F, Fonseca FG, Lobato ZI, Madureira M, Ferreira PC, Bonjardim CA, Trindade GS, Kroon EG 2010a. Human Vaccinia virus and Pseudocowpox virus coinfection: clinical description and phylogenetic characterization. J Clin Virol 48: 69-72.

Abrahão JS, Silva-Fernandes AT, Lima LS, Campos RK, Guedes MI, Cota MM, Assis FL, Borges IA, Souza-Júnior MF, Lobato ZI, Bonjardim CA, Ferreira PC, Trindade GS, Kroon EG 2010b. Vaccinia virus infection in monkeys, Brazilian Amazon. Emerg Infect Dis 16: 976-979.
Braga EM, Barros RM, Reis TA, Fontes CJ, Morais CG, Martins MS, Krettli AU 2002. Association of the IgG response to Plasmodium falciparum merozoite protein (C-terminal $19 \mathrm{kD}$ ) with clinical immunity to malaria in the Brazilian Amazon Region. Am J Trop Med Hyg 66: 461-466.

Braga EM, Fontes CJF, Krettli AU 1997. Persistence of humoral response against sporozoite and blood-stage malaria antigens 7 years after a brief exposure to Plasmodium vivax. J Infect Dis 177: 1132-1135.

Cono J, Casey CG, Bell DM, Centers for Disease Control and Prevention 2003. Smallpox vaccination and adverse reactions. Guidance for clinicians. Morb Mortal Wkly Rep 52: 1-28.

Costa GB, Moreno EG, Trindade GS, Studies Group in Bovine Vaccinia 2013. Neutralizing antibodies associated with exposure factors to Orthopoxvirus in laboratory workers. Vaccine 31: 4706-4709.

da Fonseca FG, Kroon EG, Nogueira ML, Trindade GS 2011. Zoonotic Vaccinia virus outbreaks in Brazil. Future Virol 6: 697-707.

Damaso CR, Esposito JJ, Condit RC, Moussatché N 2000. An emergent poxvirus from humans and cattle in Rio de Janeiro state: Cantagalo virus may derive from Brazilian smallpox vaccine. Virology 25: 439-449.

Damon IK 2011. Status of human monkeypox: clinical disease, epidemiology and research. Vaccine 29 (Suppl. 4): 54-59.

Damon IK 2013. Poxviruses. In DM Knipe, PM Howley (eds.), Fields virology, Lippincott Williams and Wilkins, Philadelphia, p. 2160-2184. 
de Assis FL, Vinhote WM, Barbosa JD, de Oliveira CH, de Oliveira CM, Campos KF, Silva NS, Trindade GS, Abrahão JS, Kroon EG 2013. Reemergence of Vaccinia virus during zoonotic outbreak, Pará state, Brazil. Emerg Infect Dis 19: 2017-2020.

de Sant'Ana FJ, Leal FA, Rabelo RE, Vulcani VA, Moreira Jr CR, Cargnelutti JF, Flores EF 2013. Coinfection by Vaccinia virus and an Orf virus-like parapoxvirus in an outbreak of vesicular disease in dairy cows in midwestern Brazil. J Vet Diagn Invest 25: 267-272.

Fenner F, Henderson DA, Arita I, Jezec Z, Ladnyi ID 1988. Smallpox and its eradication, World Health Organization, Geneva, $1460 \mathrm{pp}$.

Fonseca FG, Lanna MC, Campos MA, Kitajima EW, Peres JN, Golgher RR, Ferreira PC, Kroon EG 1998. Morphological and molecular characterization of the poxvirus BeAn 58058. Arch Virol 143: 1171-1186.

Hammarlund E, Lewis MW, Hansen SG, Strelow LI, Nelson JA, Sexton GJ, Hanifin JM, Slifka MK 2003. Duration of antiviral immunity after smallpox vaccination. Nat Med 9: 1131-1137.

Hatakeyama S, Moriya K, Saijo M, Morisawa Y, Kurane I, Koike K, Kimura S, Morikawa S 2005. Persisting humoral antiviral immunity within the Japanese population after the discontinuation in 1976 of routine smallpox vaccinations. Clin Diagn Lab Immunol 12: 520-524.

Kennedy RB, Ovsyannikova IG, Pankratz VS, Vierkant RA, Jacobson RM, Ryan MA, Poland GA 2009. Gender effects on humoral immune responses to smallpox vaccine. Vaccine 27: 3319-3323.

Kim SH, Yeo SG, Park KH, Bang JW, Kim HB, Kim NJ, Jee Y, Cho $\mathrm{H}$, Oh MD, Choe KW 2007. The persistence of humoral and cellular immunities more than three decades after smallpox vaccinations. Clin Microbiol Infect 13: 91-93.

Kroon EG, Mota BE, Abrahão JS, da Fonseca FG, Trindade GS 2011. Zoonotic Brazilian Vaccinia virus: from field to therapy. Antiviral Res 92: 150-163.

Lederman ER, Reynolds MG, Karem K, Bradem Z, Learned-Orozco LA, Wassa-Wassa D, Moundeli O, Hughes C, Harvey J, Regnery R, Mombouli JV, Damon IK 2007. Prevalence of antibodies against Orthopoxviruses among residents of Likouala region, Republic of the Congo: evidence for monkeypox virus exposure. $\mathrm{Am}$ J Trop Med Hyg 77: 1150-1156.

Leite JA, Drumond BP, Trindade GS, Lobato ZI, da Fonseca FG, dos Santos JR, Madureira MC, Guedes MI, Ferreira JM, Bonjardim CA, Ferreira PC, Kroon EG 2005. Passatempo virus, a Vaccinia virus strain, Brazil. Emerg Infect Dis 11: 1935-1938.

Lobato ZIP, Trindade GS, Frois MCM, Ribeiro EBT, Dias GRC, Teixeira BM, Lima FA, Almeida GMF, Kroon EG 2005. Surto de varíola bovina causada pelo vírus Vaccinia na região da Zona da Mata mineira. Arq Bras Med Vet Zootec 57: 423-429.

Lopes OS, Lacerda JP, Fonseca IE, Castro DP, Forattini OP, Rabello EX 1965. Cotia virus: a new agent isolated from sentinel mice in São Paulo, Brazil. Am J Trop Med Hyg 14: 156-157.

MacNeil A, Abel J, Reynolds MG, Lash R, Fonnie R, Kanneh LD, Robert W, Lungay VK, Goba A, Moses LM, Damon IK, Karem K, Bausch DG 2011. Serologic evidence of human Orthopoxvirus infections in Sierra Leone. BMC Res Notes 4: 465.

Megid J, Appolinário CM, Langoni H, Pituco EM, Okuda LH 2008. Vaccinia virus inhumans and cattle in southwest region of São Paulo state, Brazil. Am J TropMed Hyg 79: 647-651.

Mota BE, Trindade GS, Diniz TC, da Silva-Nunes M, Braga EM, Urbano-Ferreira M, Rodrigues GO, Bonjardim CA, Ferreira PC, Kroon EG 2010. Seroprevalence of Orthopoxvirus in an Amazonian rural village, Acre, Brazil. Arch Virol 155: 1139-1144.
Newman FK, Frey SE, Blevins TP, Mandava M, Bonifacio Jr A, Yan L, Belshe RB 2003. Improved assay to detect neutralizing antibody following vaccination with diluted or undiluted Vaccinia (Dryvax) vaccine. J Clin Microbiol 41: 3154-3157.

Peres MG, Bacchiega TS, Appolinário CM, Vicente AF, Allendorf SD, Antunes JM, Moreira SA, Legatti E, Fonseca CR, Pituco EM, Okuda LH, Pantoja JC, Ferreira F, Megid J 2013. Serological study of Vaccinia virus reservoirs in areas with and without official reports of outbreaks in cattle and humans in São Paulo, Brazil. Arch Virol 158: 2433-2441.

Reynolds MG, Carroll DS, Olson VA, Hughes C, Galley J, Likos A, Montgomery JM, Suu-Ire R, Kwasi MO, Root JJ, Braden Z, Abel J, Clemmons C, Regnery R, Karem K, Damon IK 2010. A silent enzootic of an Orthopoxvirus in Ghana, West Africa: evidence for multi-species involvement in the absence of widespread human disease. Am J Trop Med Hyg 82: 746-754.

Schatzmayr HG, Costa RV, Gonçalves MC, D’Andréa PS, Barth OM 2011. Human and animal infections by Vaccinia-like viruses in the state of Rio de Janeiro: a novel expanding zoonosis. Vaccine 29 (Suppl. 4): 65-69.

Shchelkunov SN 2013. An increasing danger of zoonotic Orthopoxvirus infections. PLoS Pathog 9: e1003756.

Silva PL, Coelho HE, Viana FC, Lucio WF, Ribeiro SCA, Oliveira PR 1986. Surto de varíola bovina no município de Prata, Minas Gerais. Arq Bras Med Vet Zootec 38: 323-330.

Silva-Fernandes AT, Travassos CE, Ferreira JM, Abrahão JS, Rocha ES, Vianna-Ferreira F, dos Santos JR, Bonjardim CA, Ferreira PC, Kroon EG 2009. Natural human infections with Vaccinia virus during bovine Vaccinia outbreaks. J Clin Virol 44: 308-313.

Singh RK, Balamurugan V, Bhanuprakash V, Venkatesan G, Hosamani M 2012. Emergence and reemergence of Vaccinia-like viruses: global scenario and perspectives. Indian J Virol 23: 1-11.

Storch GA, Wang D 2013. Diagnostic virology. In DM Knipe, PM Howley (eds.), Fields virology, Lippincott Williams and Wilkins, Philadelphia, p. 414-451.

Taub DD, Ershler WB, Janowski M, Artz A, Key ML, McKelvey J, Muller D, Moss B, Ferrucci L, Duffey PL, Longo DL 2008. Immunity from smallpox vaccine persists for decades: a longitudinal study. Am J Med 121: 1058-1064.

Trindade GS, da Fonseca FG, Marques JT, Nogueira ML, Mendes LCN, Borges AS, Peiró JR, Pituco EM, Bonjardim CA, Ferreira PC, Kroon EG 2003. Araçatuba virus: a Vaccinia-like virus associated with infection in humans and cattle. Emerg Infect Dis 9: 155-160.

Trindade GS, Drumond BP, Guedes MI, Leite JA, Mota BE, Campos MA, da Fonseca FG, Nogueira ML, Lobato ZI, Bonjardim CA, Ferreira PC, Kroon EG 2007. Zoonotic Vaccinia virus infection in Brazil: clinical description and implications for health professionals. J Clin Microbiol 45: 1370-1372.

Trindade GS, Guedes MI, Drumond BP, Mota BE, Abrahão JS, Lobato ZI, Gomes JA, Corrêa-Oliveira R, Nogueira ML, Kroon EG, da Fonseca FG 2009. Zoonotic Vaccinia virus: clinical and immunological characteristics in naturally infected patient. Clin Infect Dis 48: e37-e40.

Vora NM, Li Y, Geleishvili M, Emerson GL, Khmaladze E, Maghlakelidze G, Navdarashvili A, Zakhashvili K, Kokhreidze M, Endeladze M, Mokverashvili G, Satheshkumar PS, Gallardo-Romero N, Goldsmith CS, Metcalfe MG, Damon I, Maes EF, Reynolds MG, Morgan J, Carroll DS 2015. Human infection with a zoonotic Orthopoxvirus in the country of Georgia. N Engl J Med 372: 1223-1230. 